\title{
LEVELS OF CRUDE PROTEIN IN DIETS FOR PACU (PIARACTUS MESOPOTAMICUS) FROM 150 TO 400G REARED IN CAGES
}

\author{
NÍVEIS DE PROTEÍNA BRUTA EM DIETAS PARA PACU (PIARACTUS \\ MESOPOTAMICUS) COM 150 A 400G CULTIVADOS EM TANQUES-REDE
}

Klein, S. ${ }^{1 *}$; Lorenz, E.K. ${ }^{2}$; Bueno, G.W. ${ }^{3}$; Signor, A. ${ }^{4}$; Feiden, A. ${ }^{4}$ e Boscolo, W.R. ${ }^{4}$

\begin{abstract}
'Department of Zootechnics. University of Maringá. Brazil. *skpesca@hotmail.com
${ }^{2}$ Department of Animal Science. University of São Paulo. Brazil.

${ }^{3}$ Department of Animal Science. University of Brasilia. Brazil.

${ }^{4}$ Aquaculture Management Study Group. GEMAq. West Parana State University. Toledo. Brasil.
\end{abstract}

\section{AdDitiOnAL KEYWORDS}

Native species. Intensive system. Fish nutrition. Nutritional requirements. Juveniles.

\section{SUMMARY}

A limiting factor in the production of aquatic organisms refers to the formulation of low cost diets with protein sources that meet the nutritional requirements of animals. Therefore, this study aimed to evaluate the growth performance of reared caged pacu (Piaractus mesopotamicus) in the Itaipu reservoir. Fish with an average initial weight of $150.5 \pm 2.1 \mathrm{~g}$ were randomly distributed in 20 cages (100 fish/cage) and fed one of five levels of crude protein (CP) $(18.5,20.7,23.7,25.6$, and $28.3 \%$ ), three times a day until apparent satiety. Growth performance, muscle composition and hematological profile were evaluated. A quadratic effect was observed $(p<0.05)$ on the average final weight and average weight gain. A linear effect was observed on the feed conversion rates, moisture and muscle fat. The results from the carcass yield and hematological profiles did not present differences $(p>0.05)$. The derivation of the equations indicated that the required percentage of $\mathrm{CP}$ in the diet for juvenile pacus was $25.8 \%$. Therefore, it is recommended that pacu diets should be formulated with approximately 26 $\% \mathrm{CP}$ to ensure optimal growth performances.

\section{RESUMO}

Um factor limitante na produção de organismos aquáticos refere à formulação de dietas de baixo custo com fontes de proteínas que satisfaçam

\section{PalaVRas chaVe adicionais}

Espécies nativas. Sistema intensivo. Nutrição de peixes. Exigência nutricional. Juvenis.

as necessidades nutricionais dos animais. Portanto, este estudo teve como objetivo avaliar o desempenho e o crescimento do pacu (Piaractus mesopotamicus) cultivado em tanques-rede no reservatório de Itaipu. O peso médio inicial dos peixes foi de $150,5 \pm 2,1 \mathrm{~g}$ os quais foram distribuídos aleatoriamente em 20 tanques-rede (100 peixes/tanque) alimentados com cinco níveis de proteína bruta (PB) $(18,5 ; 20,7 ; 23,7 ; 25,6$ e $28,3 \%)$, três vezes ao dia até a saciedade aparente. Avaliou-se o crescimento, composição muscular e perfil hematológico. Observou-se feito quadrático $(p<0,05)$ no peso médio final e ganho de peso médio. Houve efeito linear na taxa de conversão alimentar, umidade e gordura muscular. Os resultados dos perfis de rendimento de carcaça e hematológico não apresentaram diferenças $(p>0,05)$. A derivação das equações indicaram que o percentual exigido de PB na dieta para juvenis de pacu foi de $25,8 \%$. Portanto, recomenda-se que as dietas para esta espécie, nestas condições de cultivo, devem ser formuladas com aproximadamente $26 \%$ de PB para assegurar melhores condições de desempenho e crescimento.

\section{INTRODUCTION}

The species Piaractus mesopotamicus, commonly known as pacu, is a native species 
in the Prata basin, Paraguay, and Uruguay and shows desirable features for farming such as high fertility rate, resilience, easy adaptation to artificial feeding (Castagnolli and Zuim, 1985), good production performance, and resistance to handling husbandry procedures (Signor et al., 2010). According to Jomori et al. (2003), this is a fast growing species with an omnivorous feeding behavior and excellent meat quality. Its omnivorous feeding behavior, according to Honorato et al. (2010), results in reduced protein requirements compared to carnivorous species because it is considered that omnivorous species can digest and metabolize carbohydrates and lipids more efficiently, thus preserving the protein for somatic growth.

The level crude protein (CP) levels in artificial diets must be tailor designed to meet nutritional requirements according to the species life stage as proteins are involved in the primary function of several biological processes. Some proteins act function as catalysts in the transportation and accommodation of molecules, in the immune system, in the generation of motion and mechanical support, in the control of the development of fish and cell differentiation (Bicudo, 2008). Proteins are composed by amino acids, which represent 65 to $75 \%$ of the total body weight of an animal in dry matter (Nelson and Cox, 2005). Whitin the whole array nutrients used in diets for fish, proteins represents the most costly portion (Abmorad and Carneiro, 2004; Bicudo et al., 2010) and are a major source of environmental pollution due to the excessive amount of nitrogen sources in these diets (Silva and Anderson, 1995).

$\mathrm{CP}$ requirements for pacu are largely unknown with and published information is scarce. Pacu CP requirements reported in two studies conducted by Fernandes et al. (2000; 2001) using pacu fry and juveniles are 26 and $22 \%$, respectively. Bicudo et al. (2010) recommends $27 \%$ CP for pacu juveniles, Cantelmo (1993) 26 and $30 \%$, and
Signor et al. (2010) recommend $25 \%$ regardless of the energetic level when correlating $\mathrm{CP}$ and digestive energy (ED).

In parallel, another factor that must be observed in nutrition studies is the hematological conditions of animals. As several studies address the effect of environmental conditions (Arnold et al., 2013), nutritional conditions (Honorato et al., 2010; Valente et al., 2013) animal handling and stress conditions on the hematological characteristics (Garcia et al., 2007; Sado et al., 2013), hematology can be considered a useful tool for monitoring health status and stress conditions that can compromise metabolism and growth of fish.

According to Clauss et al. (2008) despite recent advances on fish medicine interpretation of fish hematology is often hampered by a lack of meaningful reference values and the bewildering diversity of fish species. This emphasizes the importance of studies on hematology related with nutrition, mainly for South America native species.

Thus, this study aimed to evaluate the effect of using different CP levels on muscle composition, hematology and productive performance of cage reared pacu ( $P$. mesopotamicus) at the Itaipu reservoir.

\section{MATERIAL AND METHODS}

The experiment was conducted at the Center for the Development of Technology for Pisciculture located next to the Santa Helena Biological Sanctuary in Paraná, Brazil. The experimental period was of 74 days.

A total of $2,000 \mathrm{pacu}(150.5 \pm 2.1 \mathrm{~g})$ were randomly distributed in 20 cages with $5.0 \mathrm{~m}^{3}$. (100 fish per cage) in a set-up of five dietary treatments (with four replicate cages per treatment). In each dietary treatment fish were fed one of five experimental diets with different CP levels $(18.5 ; 20.7 ; 23.7 ; 25.6$ and $28.3 \%$ ) (table I). Diets were produced through an extrusion process at the FactorySchool of the Aquaculture Management 


\section{CRUDE PROTEIN IN THE DIET FOR PACU}

Study Group - GEMAq, West Paraná State University, Unioeste, Paraná, Brazil. Fish fed three times a day ( 9 am, 2 and 5 pm) until apparent satiety and he experimental period lasted for 74 days.

Water physical and chemical parameters with portable devices. Dissolved oxygen (Hanna Instruments, model HI9146), pH (Hanna Instruments, model HI8314), and electrical conductivity (Hanna Instruments, model HI99301) were weekly monitored as the water temperature and transparency were monitored daily (mornings and evenings) with a mercury bulb thermometer and a Secchi disk, respectively.

All fish were submitted to a period of 24 hours fasting at the end of the experiment and subsequently collected for the measurements of growth performance parameters including total length, standard length, total weight gain (Final body weight - Initial body weight), daily weight gain (Weight gain/Total days of reared), biomass gain (Initial biomass - Final niomass), apparent feed conversion (Feed intake/ Biomass gain), and survival [(Initial number

Table I. Chemical composition (\% DM) of the experimental fish diets with different CP levels. (Composição química (\% MS) das rações experimentais com diferentes níveis de PB).

\begin{tabular}{|c|c|c|c|c|c|}
\hline \multirow[b]{2}{*}{ Ingredients (\%) } & \multicolumn{5}{|c|}{ Levels of crude protein (\%) } \\
\hline & 18.5 & 20.7 & 23.7 & 25.6 & 28.3 \\
\hline Corn & 52.00 & 48.10 & 44.20 & 40.30 & 36.40 \\
\hline Poultry by-product meal & 12.50 & 15.00 & 17.50 & 20.00 & 22.50 \\
\hline Soybean meal & 3.00 & 8.60 & 14.20 & 19.80 & 25.40 \\
\hline Wheat meal & 23.00 & 19.88 & 16.76 & 13.64 & 10.52 \\
\hline Tilapia by-product meal & 3.00 & 3.00 & 3.00 & 3.00 & 3.00 \\
\hline Soybean oil & 2.96 & 2.36 & 1.77 & 1.18 & 0.59 \\
\hline Dicalcium phosphate & 1.63 & 1.30 & 0.98 & 0.65 & 0.33 \\
\hline Mineral and vitamin supplements* & 0.50 & 0.50 & 0.50 & 0.50 & 0.50 \\
\hline Sodium chloride & 0.30 & 0.30 & 0.30 & 0.30 & 0.30 \\
\hline Calcitic limestone & 0.65 & 0.54 & 0.43 & 0.32 & 0.21 \\
\hline Antifungal (Calcium propionate) & 0.10 & 0.10 & 0.10 & 0.10 & 0.10 \\
\hline Antioxidant (BHT) & 0.02 & 0.02 & 0.02 & 0.02 & 0.02 \\
\hline \multicolumn{6}{|l|}{ Chemical Composition } \\
\hline DM (\%) & 90.78 & 93.55 & 95.44 & 93.12 & 93.19 \\
\hline Nitrogen-free extract (\%) & 63.83 & 61.93 & 59.23 & 57.63 & 55.23 \\
\hline Crude protein (\%) & 18.50 & 20.70 & 23.70 & 25.60 & 28.30 \\
\hline $\mathrm{DE}(\mathrm{kcal} / \mathrm{kg})^{1}$ & 3039.00 & 3038.82 & 3038.65 & 3038.47 & 3038.30 \\
\hline Crude fiber (\%) & 2.47 & 2.62 & 2.76 & 2.91 & 3.05 \\
\hline Ash (\%) & 8.0 & 8.0 & 8.0 & 8.0 & 8.0 \\
\hline Total Phosphorus (\%) & 1.13 & 1.13 & 1.13 & 1.13 & 1.14 \\
\hline Calcium (\%) & 1.52 & 1.52 & 1.52 & 1.52 & 1.52 \\
\hline Lipids (\%) & 7.20 & 6.75 & 6.31 & 5.86 & 5.42 \\
\hline
\end{tabular}

*Premix Fish Tectron ${ }^{\circledR}$. Assured levels per kilogram of product: vit. A 1,000,000 IU; vit. D3 500,000 IU; vit. K3 500 mg; vit. B1 1,900 mg; vit. B2 2,000 mg; vit. B6 2,400 mg; vit. B12 3,500 mg; vit. E 20,000 IU; Pantothenic acid $4000 \mathrm{mg}$; folic acid $200 \mathrm{mg}$; biotin $40 \mathrm{mg}$; Niacin $5000 \mathrm{mg}$; manganese $7500 \mathrm{mg}$; Selenium $70 \mathrm{mg}$; vit. C $25000 \mathrm{mg}$; iron $12500 \mathrm{mg}$; copper 2,000 mg; iodine $200 \mathrm{mg}$.

Nitrogen-free extract $=100-($ crude protein + lipid + crude fibre + ash $) .{ }^{1}$ Calculed following Abimorad and Carneiro (2004). 
of fish*100)/ Final number of fish]. Relationships of final weight average, weight gain average, daily weight gain, apparent feed conversion, moisture and fat in the fish fed with different CP levels were assessed using regression analysis.

Four fish were collected from each cage for hematological evaluation after a 12 hours fasting period. Animals were anesthetized with Eugenol ${ }^{\circledR}$ (clove oil solution at a concentration of $60 \mathrm{mg} \mathrm{L}^{-1}$ ) according to the recommendations of Barbosa et al. (2007) and $2 \mathrm{~mL}$ of blood was subsequently collected from each fish by caudal puncture using a disposable syringe containing EDTA $(10 \%)$. Blood aliquots were diluted with Hayem solution (Collier, 1944), and the erythrocyte counts were performed in a Neubauer chamber under optical microscopy at 40x magnification. The determination of hemoglobin and hematocrit were carried out according to the methodology described by Collier (1944) and Goldenfarb et al. (1971), respectively.

The absolute hematimetric indexes (mean corpuscular volume, mean corpuscular hemoglobin, and mean corpuscular hemoglobin concentration) (Wintrobe, 1934) were calculated from the values obtained in the erythrocytes and hematocrit counts and hemoglobin rate.

The determination of the biochemical concentrations of cholesterol and blood proteins were performed in $1 \mathrm{~mL}$ of serum (without anticoagulant) using specific kits $\left(\right.$ Gold Analisa ${ }^{\circledR}$ ) and the spectrophotometric readouts were according to the manufacturer instructions. The yield was evaluated using 20 fish per treatment; these fish were anesthetized with benzocaine $\left(250 \mathrm{mg} \mathrm{L}^{-1}\right)$ and removed to be slaughtered not less than $5 \mathrm{~min}$ after ventilation stopped. The clean trunk and fillet yield, percentage of viscera, visceral fat, and hepatosomatic index were determined according to the methodology described by Vazzoler (1996).

Fillets from five fish, from each treatment's replicate, were used for pro- ximate analysis by analyzing the dry matter, moisture, crude protein, mineral matter, phosphorus, calcium and ethereal extract according to the official AOAC methods (2005).

Statistical analyses were performed by computer through the statistical analysis system, SAS (2004). The general linear models, GLM, procedure was used to fit a regression model to average fish weight, condition, survival and feed conversion ratio. Simple regression was used to evaluate differences of CP levels among diets. Duncan's multiple-range test was used to evaluate specific differences among individual diets at the 0.05 significance level. Protein Levels and final weight average, weight gain average, apparent feed conversion, moisture and fat, and their interaction were evaluated by regression according to the recommendations of Ott, (1977).

\section{RESULTSANDDISCUSSION}

The average values for the physical and chemical water parameters measured during the experimental period were $30.4 \pm 0.7^{\circ} \mathrm{C}$ for temperature; $6.40 \pm 0.3 \mathrm{mg} / \mathrm{L}$ for dissolved oxygen; $7.1 \pm 0.3$ for $\mathrm{pH} ; 48.8 \pm 14.3 \mu \mathrm{S} / \mathrm{cm}$ for electrical conductivity, and $0.06 \pm 0.03 \mathrm{mg} / \mathrm{L}$ for ammonia content. These values are within the recommended range when rearing tropical species (Boyd, 1990; Sipaúba-Tavares, 1995).

Differences in water quality among the different dietary treatments (CP levels) were not evaluated as the cages were located within the same body of water, therefore, the monitoring of parameters were jeopardized by the overtime dilution of the feed. Bechara et al. (2005) correlated the protein levels in the fish diets for pacu with the water quality in $10 \mathrm{~m} \times 15 \mathrm{~m} \times 1.5 \mathrm{~m}$ cages. These authors did not observe differences in the productive performance with increased CP levels in the diets, however, negative effects on the water quality 
Table II. Growth performance of pacu (Piaractus mesopotamicus) reared with different CP levels. (Desempenho do crescimento do pacu (Piaractus mesopotamicus) cultivado com diferentes níveis de PB).

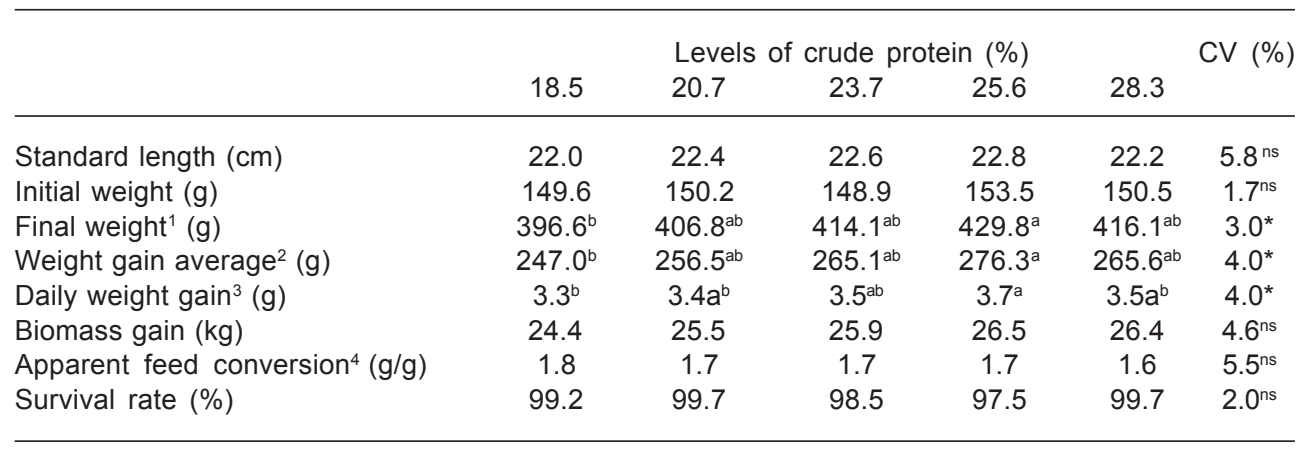

${ }^{a b}$ In the same row, means showing distinct letters are significantly different $(p<0,05)$.

${ }^{1}$ Quadratic effect: $Y=-0.491 x^{2}+25.45 x+92.51 ; R^{2}=0.82$

${ }^{2}$ Quadratic effect: $Y=-0.467 x^{2}+24.13 x-40.88 ; R^{2}=0.88$;

${ }^{3}$ Quadratic effect: $Y=-0.006 x^{2}+0.3223 x-0.536 ; R^{2}=0.76$;

${ }^{4}$ Linear effect: $Y=-0.016 x+2.080 ; R^{2}=0.79$.

parameters with increased CP content in the diet were reported.

Diets formulated with protein sources of low biological value can exhibit high contents of non-proteic nitrogen, causing an imbalance in the amino acids ratio and thus, an increase in metabolic excretion, with a consequently, negative affect on the water quality (Cho, 1990; 1992). Although the results observed in this study, demonstrated that the water quality was not affected by the different $\mathrm{CP}$ inclusion levels, such conditions must be taken into consideration when choosing the dietary protein level and availability of nutrients used to feed fish.

Fish fed with the diet with $25.6 \% \mathrm{CP}$ inclusion rate grew significantly more $(p<0.05)$ than those fed the remaining four diets. However, no significant differences ( $p>0.05$ ) were found for total body length, standard body length, apparent feed conversion and survival rate (table II).

Results showed a quadratic effect on the final weight average, weight gain average, and daily weight gain and a linear effect on the feed conversion (figure 1 and 2). After the derivation of the equations, the highest final weight average was observed in the fish fed with $25.9 \% \mathrm{CP}$; the greatest weight gain in juvenile pacus was observed when using $25.8 \% \mathrm{CP}$ (figure 1).

According to Bicudo et al. (2010), $27 \%$ $\mathrm{CP}$ inclusion was sufficient to meet the requirements of juvenile pacus. Signor et al. (2010) evaluated three CP levels (25,30, and $35 \%$ ) in diets for adult pacus cultured in cages with $5 \mathrm{~m}^{3}$ volume reared from an initial fish average weight of $293.4 \mathrm{~g}$ to average final weigth of $834.7 \mathrm{~g}$. These authors concluded that the best growth performance was achieved when fish were fed diets containing $25 \% \mathrm{CP}$. Cantelmo (1993) analysed three CP levels (26,30, and $34 \%$ ) correlated with three levels of DE $(2600,3000$, and $3400 \mathrm{kcal} / \mathrm{kg}$ of feed) and observed the best weight gain in fish fed 26 and $30 \% \mathrm{CP}$ inclusion levels regardless of the energy levels involved. Therefore, the results obtained in the present study (optimized growth performance using 25.8 $\%$ CP inclusion level) are similar and 


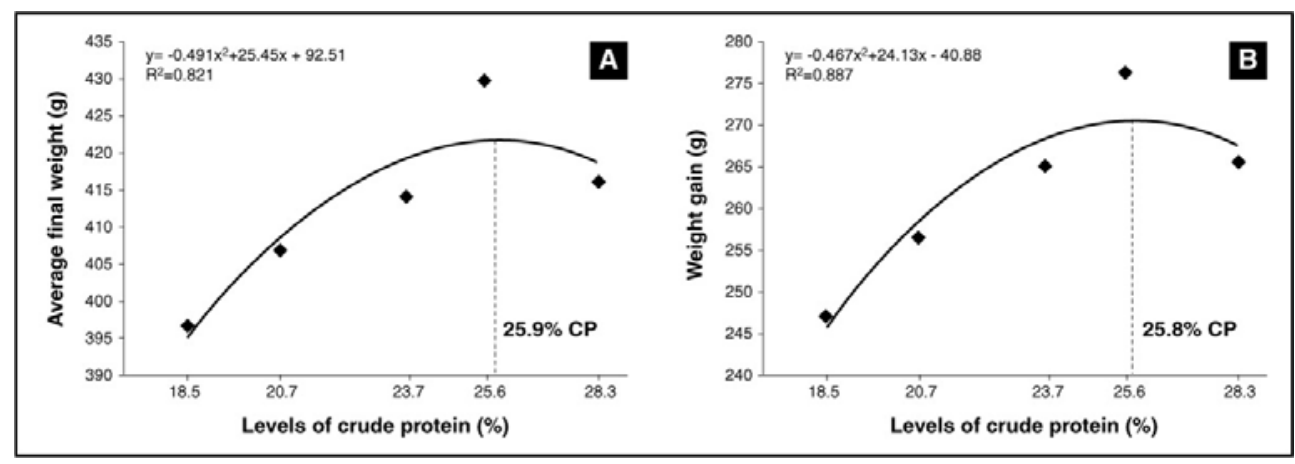

Figure 1. Quadratic effect on the final weight average $(A)$ and weight gain average $(B)$ in juvenile pacu fed with different CP levels. (Efeito quadrático sobre a média final de peso (A) e ganho de peso médio (B) de juvenis de pacu alimentados com diferentes níveis de PB).

corroborate the above mentioned studies.

In studies with fry pacu (4.6 and $11,3 \mathrm{~g})$ by Fernandes et al. (2000), and juveniles pacus ( 80 and $144,3 \mathrm{~g})$ Fernandes et al. (2001), using different protein levels and protein sources in the diet, these authors conclued that the fish meal can be partially or entirely replaced by soybean meal in artificial diets for fry and juvenile pacu. These authors also suggest $26 \%$ and $22 \%$ as optimal CP inclusion levels respectively, for fry and for juvenile pacu.

In this study, all diets were formulated to contain an average of $53 \%$ of CP from plant sources and $47 \%$ from animal sources. This combination between protein sources has been considered ideal to improve growth performance as it provides a superior profile of essential amino acids and availability of calcium and phosphorus (Pezzato et al., 2002; Guimarães et al., 2008).

However, imbalance amino acid (AA) can affect the overall intake rate, nutriente transportation, catabolism, rate of synthesis and degradation of muscle tissue and formation of toxic metabolites (Jaramillo, 1996). In addition, this AA imbalance can lead to a reduction in the protein utilization,
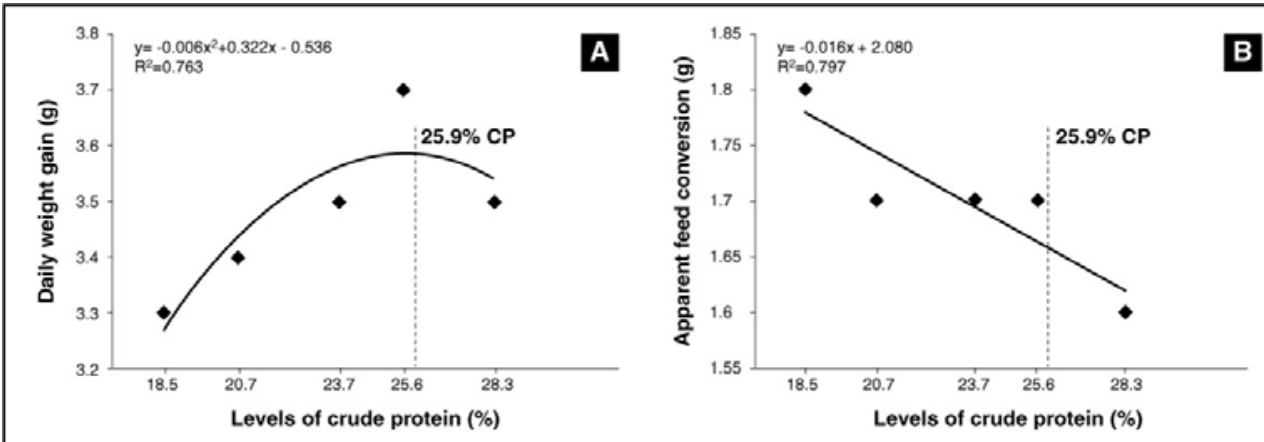

Figure 2. Quadratic effect on daily weight gain (A) and linear effect on the apparent feed conversion (B) in juvenile pacu fed with different $C P$ levels. (Efeito quadrático sobre o ganho de peso diário $(A)$ e efeito linear sobre a conversão alimentar aparente $(B)$ dos juvenis de pacu alimentados com diferentes níveis de PB).

Archivos de zootecnia vol. 63, num. 244, p. 604. 
Table III. Average values for carcass yield in pacu reared with different CP levels. (Valores médios do rendimento de carcaça de pacu cultivado com diferentes níveis de PB).

\begin{tabular}{lccccccc}
\hline & \multicolumn{3}{c}{ Levels of crude protein (\%) } & \multicolumn{3}{c}{ CV (\%) } \\
& 18.5 & 20.7 & 23.7 & 25.6 & 28.3 & \\
\hline Eviscerated body (\%) & 53.03 & 54.46 & 52.71 & 55.53 & 53.44 & 9.68 \\
Fillet (\%) & 37.07 & 37.43 & 36.60 & 38.73 & 37.85 & 7.71 \\
Visceral fat index (\%) & 3.71 & 3.04 & 3.70 & 4.19 & 3.38 & 46.41 \\
Hepatosomatic index (\%) & 0.86 & 0.80 & 0.89 & 0.84 & 0.85 & 40.64 \\
\hline
\end{tabular}

Not significant differences $(p>0.05)$.

which will affect growth and will result in lower weight gain and higher susceptibility to diseases (Pezzato et al., 2004).

The feed conversion and survival were not significantly different $(\mathrm{p}>0.05)$ between the five dietary treatments, however the observed average feed conversion of 1.7 was different from the 3.31 reported by Fernandes et al. (2001) as the best index, and from the 2.88 reported by Signor et al. (2010). Nonetheless, the survival rate observed in these two studies are similar to the results observed in this current study. Scorvo Filho et al. (1998) identified zootechnical parameters for round fish (including pacu) with feed conversion between 1.6 and 1.8 for fish reared in ponds.

The parameters of carcass yield did not show significant differences $(\mathrm{p}>0.05)$ when subjected to the regression analysis. The average values for the carcass yield are presented in table III.

Distinct results were observed by Signor et al. (2010) for the average values of carcass yield, which is mainly due to differences in fish final weight averages of $834.7 \mathrm{~g}$ compared to $412.7 \mathrm{~g}$ in the current study. Faria et al. (2003) observed fillet percentages from 46.7 to $51.6 \%$ when studying the efficiency of pacu processing. These values are probably discrepant from the values observed in this study (from 36.6 to $38.7 \%$ ) because the size of the fish slaughtered. Souza and Maranhão (2001) identified differences in yield during fish processing due to fish size.

The percentages of visceral fat were not affected by the levels of protein in the diet, and the observed values are within the range observed by Macedo-Viegas et al. (2000). The percentage of visceral fat is directly affected by the developmental phase; greater accumulation of visceral fat is observed with the increase in size (Signor et al., 2010). Muñoz-Ramírez and Carneiro (2002) reported fat visceral-somatic indexes between 2.8 and 2.8 in pacu fingerlings. Because this parameter is directly related to nutrient availability energy relationship between diets from different lipid sources (Abimorad et al., 2007) and concentration of existing carbohydrates (Baldan, 2008), it can be inferred that the diets provided to fish had a proper nutritional balance as no variations in the hepatosomatic index were not observed.

According to Brauge et al. (1994), absorbed carbohydrates are deposited in the form of glycogen in the liver instead of being used in the metabolic pathways for energy. According to Hemre et al. (1995) and Deng et al. (2000), in these conditions, carbohydrates can produce a protein sparing effect improving the protein usage rate.

An increase in moisture and a decrease in the animal tissue fat contents were observed with the increase of protein levels in the diets used (table IV, figure 3). This relationship highlighted by Bicudo et al. 
Table IV. Chemical analyses of pacu fillets reared with different CP levels (natural matter basis).(Análise química do filé de pacu cultivado com diferentes níveis de PB (base na material natural).

\begin{tabular}{lccccccc}
\hline & \multicolumn{3}{c}{ Levels of crude protein (\%) } & \multicolumn{3}{c}{ CV (\%) } \\
& 18.5 & 20.7 & 23.7 & 25.6 & 28.3 & \\
\hline Moisture $^{1}$ & $69.04^{\mathrm{b}}$ & $71.48^{\mathrm{a}}$ & $70.71^{\mathrm{ab}}$ & $70.81^{\mathrm{ab}}$ & $72.65^{\mathrm{a}}$ & \multirow{2}{*}{1.44} \\
Crude protein $_{\text {Crude fat }}{ }^{2}$ & 16.72 & 15.98 & 16.50 & 17.15 & 16.91 & 6.00 \\
Ash & $11.88^{\mathrm{a}}$ & $10.12^{\mathrm{ab}}$ & $10.16 \mathrm{a}^{\mathrm{b}}$ & $10.33^{\mathrm{ab}}$ & $8.00^{\mathrm{b}}$ & 9.78 \\
& 1.27 & 1.22 & 1.20 & 1.30 & 1.31 & 7.42 \\
\hline
\end{tabular}

${ }^{a b}$ In the same row, means showing distinct letters are significantly different $(p<0.05)$.

${ }^{1}$ Linear effect: $y=0,0263 x+64.7853 ; R^{2}=0.60$;

2Linear effect: $y=0,031 x+17.2815 ; R^{2}=0.75$.

(2010), who reported a direct effect of the nutritional composition of diets on the composition of nutrients accumulated in the tissues. Kaushik and Oliva-Teles (1985) and Lanari et al. (1999) report that the ratio of carbohydrates in fish diets can sig- nificantly affect the concentration of fat tissue. In this study, the increased protein level in the diets led to a reduction in carbohydrates, and consequently, influenced the nutrient composition observed in the tissues as also evidenced by Coutteau

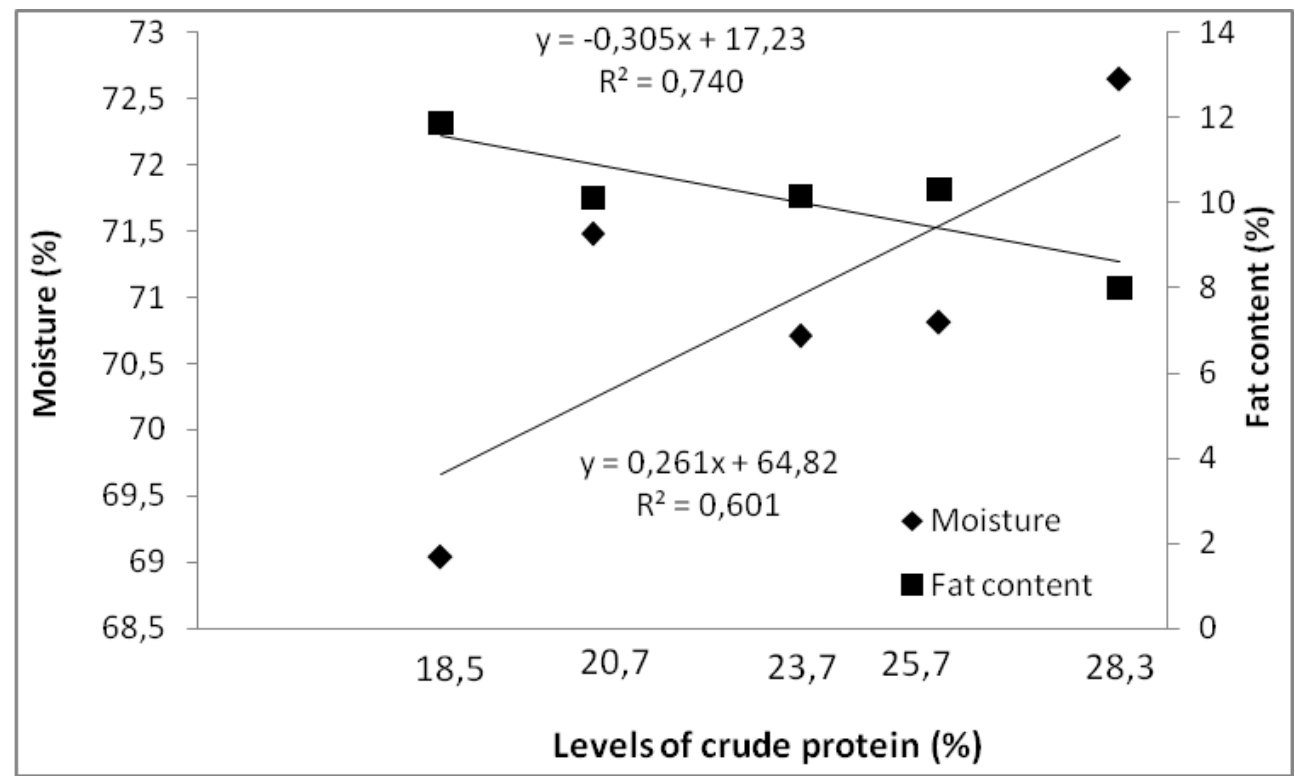

Figure 3. Linear effect on moisture and fat in pacu fed with different CP levels. (Efeito linear sobre a umidade e gordura do pacu alimentado com diferentes níveis de PB).

Archivos de zootecnia vol. 63, num. 244, p. 606. 
Table $\boldsymbol{V}$. Hematological and biochemical variables in pacu reared with different CP levels. (Variáveis hematológicas e bioquímicas do pacu cultivado com diferentes níveis de PB).

\begin{tabular}{|c|c|c|c|c|c|c|}
\hline & \multicolumn{5}{|c|}{ Levels of crude protein (\%) } & \multirow{2}{*}{ CV (\%) } \\
\hline & 18.5 & 20.7 & 23.7 & 25.6 & 28.3 & \\
\hline \multicolumn{7}{|l|}{ Hematological } \\
\hline Hematocrit (\%) & 37.69 & 38.31 & 38.4 & 36.67 & 38.06 & 5.90 \\
\hline Hemoglobin (g/dL) & 7.14 & 7.68 & 7.36 & 7.48 & 8.43 & 9.27 \\
\hline Eritrocytes $\left(10^{6} / \mu \mathrm{l}\right)$ & 2.11 & 2.01 & 2.02 & 1.89 & 2.07 & 11.97 \\
\hline ACV (fL) & 182.11 & 193.36 & 192.19 & 193.67 & 186.03 & 13.30 \\
\hline $\mathrm{ACH}(\mathrm{g} / \mathrm{dL})$ & 34.40 & 38.77 & 36.84 & 39.47 & 40.83 & 12.72 \\
\hline $\mathrm{ACHC}(\mathrm{g} / \mathrm{dL})$ & 19.05 & 20.22 & 19.15 & 20.48 & 22.26 & 12.94 \\
\hline \multicolumn{7}{|l|}{ Biochemical } \\
\hline Cholesterol (mg/dL) & 268.94 & 228.34 & 242.49 & 209.37 & 222.2 & 14.74 \\
\hline Total protein $(\mathrm{g} / \mathrm{dL})$ & 7.67 & 5.93 & 6.92 & 5.72 & 6.45 & 25.48 \\
\hline
\end{tabular}

Not significant differences ( $p>0.05)$.

$\mathrm{ACV}=$ Average corpuscular volume $\mathrm{ACH}=$ Average corpuscular hemoglobin. $\mathrm{ACHC}=$ Average corpuscular hemoglobin concentration.

et al. (2000).

According to Zuim et al. (1988), the percentage of hematocrit is higher in adult fish rather than in juvenile $P$. mesopotamicus. This was also evidenced by Bicudo et al. (2009) and Bittencourt et al. (2010), who analyzed two different size pacus (56 and 1,107 g average weight), and hematocrit values ranged from 32.9 to $41.4 \%$, respectively. In the present study, the observed average hematocrit values were $37.8 \%$ (table V) evidencing that larger fish tend to present higher values compared to smaller fish.

According to Garcia-Navarro and Pachally (2005) and Ranzani-Paiva and Silva-Souza (2004), hematologic evaluations are informative of infectious diseases, leukemia's, environmental stress and the physiological state of the organism. The results obtained from the hematological analyses demonstrated not only that the protein levels contained in the diets did not influence in the fish health, but also, that the experimental design and rearing conditions were adequate and did not induce any kind of environmental stress to the fish.

\section{CONCLUSION}

The results obtained from the hematological analyses demonstrated not only that the protein levels contained in the diets did not influence in the fish health, but also, that the experimental design and rearing conditions were adequate and did not induce any kind of environmental stress to the fish.

Under the experimental conditions of this study, the optimized growth performance in reared caged pacu, P. mesopotamicus, was obtained when fish were fed diets containing approximately $26 \%$ crude protein.

\section{ACKNOWLEDGEMENTS}

The authors are thankful to ITAIPU BINACIONAL for the research grant Cultivating quality water number CV4500008796 and to UNIOESTE/GEMAq for the financial and logistic support and research fellowship recipients from Brazilian National Council (CNPq) and Coordination of Improvement of Higher Education Personnel(CAPES). 


\section{KLEIN, LORENZ, BUENO, SIGNOR, FEIDEN E BOSCOLO}

\section{REFERENCES}

Abimorad, E.G.; Carneiro, D.J. and Urbinati, E.C. 2007. Growth and metabolism of pacu (Piaractus mesopotamicus Holmberg 1887) juveniles fed diets containing different protein, lipid and carbohydrate levels. Aquac Res, 38: 36-44.

Abimorad, E.G and Carneiro, D.J. 2004. Métodos de coleta de fezes e determinação dos coeficientes de digestibilidade da fração protéica e da energia de alimentos para o pacu, Piaractus mesopotamicus (Holmberg, 1887). Rev Bras Zootecn, 33: 1101-1109.

AOAC. 2005. Official Methods of Analysis of AOAC International. 18 ed. AOAC. Gaithersburg, M.D. USA.

Arnold, M.B.; Torrans, E.L. and Allen, P.J. 2013. Influences of cyclic, high temperatures on juvenile channel catfish growth and feeding. Aquaculture, 75: 77-84.

Baldan, A.P. 2008. Avaliação da tolerância do pacu (Piaractus mesopotamicus) a carboidratos. Tese (Doutorado) Pós-graduação em Aquicultura. Universidade Estadual Paulista. Centro de Aquicultura da Unesp. CAUNESP. Jaboticabal, SP. 119 pp.

Barbosa, L.G.; Moraes, G. e Inoue, L.A.K. 2007. Respostas metabólicas do matrinxã submetidos a banho anestésico de eugenol. Acta Scient Biol Sci, 29: 255-260.

Bechara, J.A.; Roux, J.P.; Ruiz Díaz, F.J.; Flores Quintana, C.I. and Longoni de Meabe, C.A. 2005. The effect of dietary protein level on pond water quality and feed utilization efficiency of pacu Piaractus mesopotamicus (Holmberg, 1887). Aquac Res 36: 546-553.

Bicudo, A.J.A. 2008. Exigências nutricionais de juvenis de pacu (Piaractus mesopotamicus Holmberg, 1887): proteína, energia e aminoácidos. Dissertation. Universidade de São Paulo. Piracicaba. 24 pp.

Bicudo, A.J.A.; Sado, R.Y. and Cyrino, J.E.P. 2009. Growth and haematology of pacu, Piaractus mesopotamicus, fed diets with varying protein to energy ratio. Aquac Res, 40: 486-495.

Bicudo, A.J.A.; Sado, R.Y. and Cyrino, J.E.P. 2010. Growth performance and body composition of pacu Piaractus mesopotamicus (Holmberg 1887 ) in response to dietary protein and energy levels. Aquac Nutr, 16: 213-222.
Bittencourt, F.; Feiden, A.; Signor, A.A.; Boscolo, W.R.; Lorenz, E.K. e Maluf, M.L.F. 2010. Densidade de estocagem e parâmetros eritrocitários de pacus criados em tanquesrede. Rev Bras Zootecn, 39: 2323-2329.

Boyd, C.E. 1990. Water quality in ponds for aquaculture. Alabama Agricultural Experiment Station. Auburn University (Auburn University, Ala.). Auburn.

Brauge, C.; Medale, F. and Corraze, G. 1994. Effect of dietary carbohydrate levels on growth, body composition and glycaemia in rainbow trout, Oncorhynchus mykiss, reared in seawater. Aquaculture, 123: 109-120.

Cantelmo, O.A. 1993. Níveis de proteína e energia em dietas para o crescimento do pacu Piaractus mesopotamicus (Holmberg, 1887). Dissertation. Universidade Federal de Santa Catarina. Florianópolis. $55 \mathrm{pp}$.

Castagnolli, N. e Zuim, S.M.F. 1985. Consolidação do conhecimento adquirido sobre o pacu Colossoma mitrei (Berg,1895). FCAV/UNESP. Jaboticabal. 26 pp.

Cho, C.Y. 1990. Fish nutrition, feeds, and feeding: With special emphasis on salmonid aquaculture. Fd Rev Int, 6: 333-357.

Cho, C.Y. 1992. Feeding systems for rainbow trout and other salmonids with reference to current estimates of energy and protein requirements. Aquaculture, 100: 107-123.

Clauss, T.M.; Dove, A.D.M. and Arnold, J.E. 2008. Hematologic disorders of fish. Vet Clin Exot Anim, 11: 445-462.

Collier, H.B. 1944. Standardization of blood haemoglobin determinations. Can Med Ass J, 50: 550-552.

Coutteau, P.; Kontara, E.K.M. and Sorgeloos, P. 2000. Comparison of phosphatidylcholine purified from soybean and marine fish roe in the diet of postlarval Penaeus vannamei Boone. Aquaculture, 181: 331-345.

Deng, D.F.; Refstie, S.; Hemre, G.I.; Crocker, C.E.; Chen, H.Y.; Cech, J.J. and Hung, S.S.O. 2000. A new technique of feeding, repeated sampling of blood and continuous collection of urine in white sturgeon. Fish Physiol Biochem, 22: 191-197.

Faria, R.H.S.; Souza, M.L.R.; Wagner, P.M.; Povh,

Archivos de zootecnia vol. 63, num. 244, p. 608. 


\section{CRUDE PROTEIN IN THE DIET FOR PACU}

J.A. e Ribeiro, R.P. 2003. Rendimento do processamento da tilapia do Nilo (Oreochroms niloticus Linnaeus, 1757) e do pacu (Piaractus mesopotamicus Holmberg, 1887). Acta Scient Anim Sci, 25: 21-24.

Fernandes, J.B.K.; Carneiro, D.J. e Sakomura, N.K. 2000. Fontes e níveis de proteína bruta em dietas para alevinos de pacu (Piaractus mesopotamicus). Rev Bras Zootecn, 29: 646653.

Fernandes, J.B.K.; Carneiro, D.J. e Sakomura, N.K. 2001. Fontes e níveis de proteína bruta em dietas para juvenis de pacu (Piaractus mesopotamicus). Rev Bras Zootecn, 30: 617626.

Garcia, F.; Pilarski, F.; Onaka, E. M.; Moraes, F.R.; Martins, M.L. 2007. Hematology of Piaractus mesopotamicus fed diets supplemented with vitamins $C$ and $E$, challenged by Aeromonas hydrophila. Aquaculture, 271: 3946.

Garcia-Navarro, C.E.K. e Pachaly, J.R. 2005. Manual de Hematologia Veterinária. $2^{\text {nd }}$ ed. Editora Varela. São Paulo.

Goldenfarb, P.B.; Bowyer, F.P.; Hall, E.; Brosious, E. 1971. Reproducibility in the hematology laboratory: the microhematocrit determination. Reproducibility in the hematology laboratory: the microhematocrit determination. Am J Clin Pathol, 56:35-39.

Guimarães, I.G.; Pezzato, L.E. and Barros, M.M. 2008. Amino acid availability and protein digestibility of several protein sources for Nile tilapia, Oreochromis niloticus. Aquac Nutr, 14: 396-404.

Hemre, G.I.; Sandnes, K.; Lie, Ø.; Torrissen, O. and Waagbø, R. 1995. Carbohydrate nutrition in Atlantic salmon, Salmo salar L.: growth and feed utilization. Aquac Res, 26: 149-154.

Honorato, C.A.; Almeida, L.C.; Da Silva Nunes, C.; Carneiro, D.J. and Moraes, G. 2010. Effects of processing on physical characteristics of diets with distinct levels of carbohydrates and lipids: the outcomes on the growth of pacu (Piaractus mesopotamicus). Aquac Nutr, 16: 91-99.

Jaramillo, M.P.S. 1996. Nutrientes esenciales. In: Jaramillo, M.P.S.; Gomes, H.R. y Daza, P.V. (Eds.). Fundamentos de nutrición y alimentación en acuicultura. Ministerio de Agricultura y Desarrollo Rural. Instituto Nacional de Pesca y
Acuicultura. Santafé de Bogota. República de Colombia. pp. 53-63.

Jomori, R.K.; Carneiro, D.J.; Malheiros, E.B. and Portella, M.C. 2003. Growth and survival of pacu Piaractus mesopotamicus (Holmberg, 1887) juveniles reared in ponds or at different initial larviculture periods indoors. Aquaculture, 221: 277-287.

Kaushik, S.J. and de Oliva Teles, A. 1985. Effect of digestible energy on nitrogen and energy balance in rainbow trout. Aquaculture, 50: 89101.

Lanari, D.; Poli, B.M.; Ballestrazzi, R.; Lupi, P.; D'Agaro, E. and Mecatti, M. 1999. The effects of dietary fat and NFE levels on growing European sea bass (Dicentrarchus labrax L.). Growth rate, body and fillet composition, carcass traits and nutrient retention efficiency. Aquaculture, 179: 351-364.

Macedo-Viegas, E.M.; Scorvo, C.M.D.F.; Vidotti, R.M. e Secco, E.M. 2000. Efeito das classes de peso sobre a composição corporal e o rendimento de processamento de matrinxã (Brycon cephalus). Acta Scient Anim Sci, 22: 725-728.

Muñoz-Ramírez, A.P. e Carneiro, D.J. 2002. Suplementação de lisina e metionina em dietas com baixo nível protéico para o crescimento inicial do pacu, Piaractus mesopotamicus (Holmberg). Acta Scientiarum, 24: 909-916.

Nelson, D.L. and Cox, M.M. 2005. Lipids. In: Lehninger, A.L.; Nelson, D.L. and Cox, M.M. (Eds.). Lehniger principles of biochemistry. W.H. Freeman and Company. New York.

Ott, L. 1977. An introduction to statistical methods and data analysis. Wadsworth. Belmont. $730 \mathrm{p}$.

Pezzato, L.E.; Miranda, E.C.; Barros, M.M.; Pinto, L.G.Q.; Furuya, W.M. e Pezzato, A.C. 2002. Digestibilidade aparente de ingredientes pela tilápia do Nilo (Oreochromis niloticus). Rev Bras Zootecn, 31: 1595-1604.

Pezzato, L.E.; Barros, M.M.; Fracalossi, D.M. e Cyrino, J.E.P. 2004. Nutrição de peixes. In: Cyrino, J.E.P.; Urbinati, E.C.; Fracalossi, D.M. e Castagnolli, N. (Eds.). Tópicos especiais em piscicultura de água doce tropical intensiva. TecArt. São Paulo. pp. 79.

Ranzani-Paiva, M.J.T. e Silva-Souza, A.T. 2004. Hematologia de peixes brasileiros. In: RanzaniPaiva, M.J.T.; Takemoto, R.M. e Lizama, M.A.P. (Eds.). Sanidade de organismos aquáticos. 


\section{KLEIN, LORENZ, BUENO, SIGNOR, FEIDEN E BOSCOLO}

Livraria Varela. São Paulo. pp. 442.

Sado, R.Y.; Bicudo, A.J.A. and Cyrino, J.E.P. 2013.

Growth and hematology of juvenile pacu Piaractus mesopotamicus (Holmberg 1887) fed with increasing levels of vitamin $E$ (DL- \pmtocopheryl acetate). Acad Bras Ciênc, 85: 385393.

SAS. 2004. SAS Institute Inc. SAS statistics User's Guide ( $9^{\text {th }}$ ed). Cary. North Caroline. USA.

Scorvo Filho, J.D.; Martins, N.B. e Ayroza, L.M.S. 1998. Piscicultura em São Paulo: custos e retornos de diferentes sistemas de produção na safra de 1996/1997. Inform Econ, 8: 41-60.

Signor, A.A.; Boscolo, W.R.; Feiden, A.; Bittencourt, F.; Coldebella, A. e Reidel, A. 2010. Proteína e energia na alimentação de pacus criados em tanques-rede. Rev Bras Zootecn, 39: 23362341.

Silva, S.S. and Anderson, T.A. 1995. Fish nutrition in Aquaculture. Chapman and Hall. London.

Sipaúba-Tavares, L.H.S. 1995. Limnologia aplicada à aquicultura. Funep. Jaboticabal. 70 pp.
Souza, M.L.R. e Maranhão, T.C.F. 2001. Rendimento de carcaça, filé e subprodutos da filetagem da tilápia do Nilo, Oreochromis niloticus (L), em função do peso corporal. Acta Scient Anim Sci, 23: 897-901.

Valente, L.M.P.; Moutou, K.A.; Conceição, L.E.C.; Engrola, S.; Fernandes, J.M.O. and Johnston, I.A. 2013. What determines growth potential and juvenile quality of farmed fish species? Rev Aquacult, 5: 168-193.

Vazzoler, A.E.A.M. 1996. Biologia da reproducao de peixes teleosteos: teoria e pratica. Nupélia Eduem. Maringá.

Wintrobe, M.M. 1934. Variations in the size and hemoglobin content of erythrocytes in the blood of various vertebrates. Folia Hematol, 51: 3249.

Zuim, S.M.F.; Rosa, A.A.M. and Castagnolli, N. 1988. Sex and sexual cycle influences over metabolic parameters in pacu Piaractus mesopotamicus (Holmberg, 1887). Bulletin Can Aquac Ass Proc, 88: 55-56. 